\title{
The Expression and Function of G-Proteins in Experimental Intimal Hyperplasia
}

\author{
Mark G. Davies, * Vickram Ramkumar, ${ }^{5}$ Tom W. Gettys, " and Per-Otto Hagen ${ }^{\star *}$ \\ Vascular Biology and Atherosclerosis Research Laboratory, Departments of * Surgery and ${ }^{\ddagger}$ Biochemistry, Duke University Medical \\ Center, Durham, North Carolina 27710; ${ }^{8}$ Department of Pharmacology, Southern Illinois University School of Medicine, Springfield,
} Illinois 62794; and "Department of Medicine, Medical University of South Carolina, Charleston, South Carolina 29425

\begin{abstract}
G-proteins are membrane-bound signal transduction proteins which couple extracellular receptor signals to various effectors. This study examines the expression and the function of G-proteins $\left(\alpha_{i}, \alpha_{s}, \alpha_{q}\right.$, and $\left.\alpha_{0}\right)$ in experimental intimal hyperplasia. Vein bypass grafts were placed in $30 \mathrm{New}$ Zealand White rabbits and were harvested after $28 \mathrm{~d}$. The contralateral jugular veins served as controls. Isometric tension studies were performed on rings from veins and vein grafts $(n=10)$, and Western blot and mRNA analyses were performed in another 20 vessels. There was a fivefold increase in $\alpha_{q}$, a 2.7-fold increase in the $\alpha_{i 2}$, and a 3.3fold increase in $\alpha_{\mathrm{S}}$ expressions in vein grafts compared with veins. Detectable expression of $\alpha_{13}$ was observed in vein grafts but not in jugular veins. In addition, there was a 3.8fold increase in $\beta$ subunits in the vein grafts compared with the veins. mRNA for $\alpha_{s}, \alpha_{13}$, and $\alpha_{12}$ were all elevated in the vein grafts. No detectable levels of the $\alpha_{i 1}$ protein or its mRNA were present in either veins or vein grafts. Contractile responses in the veins were not inhibited by pertussis toxin. The contractile responses to norepinephrine were enhanced by twofold, and the responses to serotonin developed de novo in vein grafts compared with veins. The contractile responses to both norepinephrine and serotonin were only partially inhibited by pertussis toxin in the vein grafts even though there was $100 \%$ ADP ribosylation with pertussis toxin in both veins and vein grafts. These data suggest that intimal hyperplasia is associated with increased or novel expression of G-proteins in vivo which occur simultaneously with the development of pertussis toxin-sensitive contractile responses. Changes in G-proteins at a transcriptional level or at the level of RNA stability may be involved in the response of smooth muscle cells to injury and to intimal hyperplasia formation. (J. Clin. Invest. 1994. 94:16801689.) Key words: G-proteins $\bullet$ smooth muscle cells $\bullet$ intimal hyperplasia $\cdot$ vein graft $\cdot$ rabbit
\end{abstract}

Address correspondence to Per-Otto Hagen, Ph.D., Duke University Medical Center, P.O. Box 3473, Durham, NC 27710.

Received for publication 18 August 1993 and in revised form 6 July 1994.

J. Clin. Invest.

(C) The American Society for Clinical Investigation, Inc.

$0021-9738 / 94 / 10 / 1680 / 10 \quad \$ 2.00$

Volume 94, October 1994, 1680-1689

\section{Introduction}

Vein bypass grafts develop intimal hyperplasia, a lesion that can lead to stenosis and subsequent occlusion $(1,2)$. In addition, the vasomotor function of these veins in response to several agonists is modulated after insertion into the arterial circulation as vein grafts in both human and experimental preparations (3-6). In the rabbit model, vein grafts show an increased response to norepinephrine and, additionally, develop a 5- $\mathrm{HT}_{2}$-mediated contractile response to serotonin $(7,8)$. The change in norepinephrine responsiveness and the development of a serotonin response suggest that there may be significant changes in the smooth muscle cells of the vein grafts compared with their venous progenitors with perhaps the development of a new smooth muscle cell phenotype as suggested by Ross (9). In particular, changes in responsiveness to norepinephrine and serotonin may be due to alterations in the expression of G-proteins to which these receptors are coupled. The expression and the function of G-proteins in the vascular smooth muscle cells of the intimal hyperplasia and, thus, their role in the pathophysiology of vein graft restenosis are unknown. This study addresses these questions by examining the expression and the functional coupling of G-proteins $\left(\alpha_{\mathrm{i}}, \alpha_{\mathrm{s}}, \alpha_{\mathrm{q}}\right.$, and $\left.\alpha_{0}\right)$ in experimental intimal hyperplasia of vein bypass grafting.

\section{Methods}

30 male New Zealand White rabbits, weighing $2-2.5 \mathrm{~kg}$, underwent a reversed jugular vein interposition bypass of the right common carotid artery using the ipsilateral external jugular vein. At $28 \mathrm{~d}$, all animals were killed with an overdose of barbiturates, and both the vein graft and contralateral jugular vein were harvested. Three vein grafts were harvested for histology. The remaining jugular veins and vein grafts were used for G-protein analyses and ADP ribosylation studies, vasomotor function studies to norepinephrine and serotonin (with and without pertussis toxin), and the determination of adenylate nucleotides. Animal care complied with the Principles of Laboratory Animal Care as formulated by the National Society for Medical Research and the Guide for the Care and Use of Laboratory Animals issued by the National Institutes of Health (U. S. Department of Health and Human Services, NIH Publication No. 80-23, revised 1985).

\section{Operative procedure}

Anesthesia was induced and maintained with subcutaneously injected ketamine hydrochloride $(60 \mathrm{mg} / \mathrm{kg}$, Ketaset; Bristol Laboratories, Syracuse, NY) and xylazine ( $6 \mathrm{mg} / \mathrm{kg}$, Anased; Llyod Laboratories, Shenandoah, IA). Antibiotic prophylaxis with $30,000 \mathrm{IU} / \mathrm{kg}$ of benzanthine and procaine penicillin (Durapen; Vedco Inc., Overland Park, KS) was given intramuscularly at the time of induction. Surgery was performed 


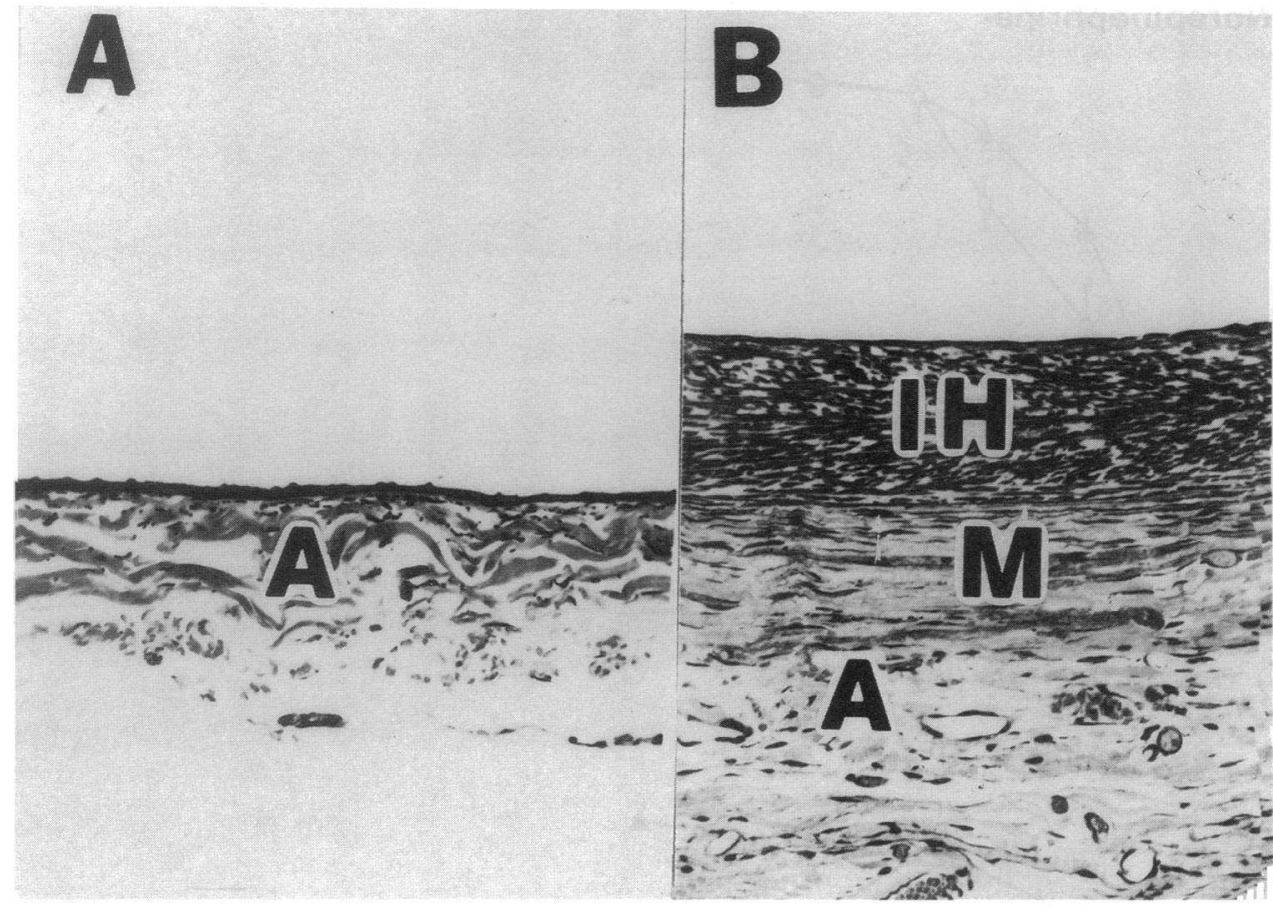

Figure 1. A composite photomicrograph showing a cross-section from the wall of a jugular vein $(A)$ and a vein graft $(B)$ stained with a modified Masson's trichrome and Verhoeff's elastin stain. $I H$, intimal hyperplasia; $M$, media; and $A$, adventitia. $\times 100$. using an operating microscope (JKH 1402; Edward Weck Inc., Research Triangle Park, NC) under sterile conditions. After exposure through a midline longitudinal neck incision, the right external jugular vein was identified, its branches were diathermied at a distance from the vein to minimize injury, and it was then dissected out. After excision, the vein was kept moist in a heparinized Ringer lactate solution $(5 \mathrm{IU} / \mathrm{ml}$, heparin; Elkins-Sinn Inc., Cherry Hill, NJ) for $\sim 15 \mathrm{~min}$ while the right common carotid artery was identified, dissected, and both proximal and distal control obtained. Heparin $(200 \mathrm{IU} / \mathrm{kg}$ ) was administered intravenously. A proximal longitudinal arteriotomy was made, and one end of the reversed jugular vein was anastomosed to the artery in an end-to-side manner using continuous 10-O microvascular monofilament nylon suture (Ethilon; Ethicon Inc., Somerville, NJ). The distal anastomosis was performed in a similar manner. Throughout the procedure, care was taken to avoid unnecessary instrumentation of the vein graft. The right common carotid was ligated and divided between the two anastomoses with 4-O silk sutures, and the wound was closed in layers.

\section{Morphology}

Three vein grafts were harvested $28 \mathrm{~d}$ after surgery. After isolation and systemic heparinization (200 IU/ $\mathrm{kg}$, intravenously), the vein grafts were perfusion fixed in situ at $80 \mathrm{mmHg}$ with an initial infusion of Hanks' balanced salt solution (HBSS; Gibco Laboratories, Grand Island, $\mathrm{NY}$ ) followed by $2 \%$ glutaraldehyde made up in $0.1 \mathrm{M}$ cacodylate buffer ( $\mathrm{pH} 7.2$ ) supplemented with $0.1 \mathrm{M}$ sucrose to give an osmolality of $\sim 300$ mosmol. After $60 \mathrm{~min}$, the specimen was removed and immersed in the glutaraldehyde fixative for a further $24 \mathrm{~h}$. Cross-sections from the mid-portion of the vein graft were processed for light microscopy. Following standard histological procedures, each specimen was stained with a modified Masson's trichrome and Verhoeff's elastin stain, and dimensional analysis was performed by videomorphometry (Innovision 150; American Innovision Inc., San Diego, CA).

\section{Isometric tension studies}

Under anesthesia, the original incision was reopened, and the jugular vein and vein graft were isolated. The midpart of each vessel was sectioned in situ into two 5-mm segments and excised. These rings were suspended immediately from two stainless steel hooks in 5-ml organ baths containing oxygenated Krebs solution ( $122 \mathrm{mM} \mathrm{NaCl}, 4.7 \mathrm{mM}$ $\mathrm{KCl}, 1.2 \mathrm{mM} \mathrm{MgCl}, 2.5 \mathrm{mM} \mathrm{CaCl}, 15.4 \mathrm{mM} \mathrm{NaHCO}, 1.2 \mathrm{mM}$ $\mathrm{KH}_{2} \mathrm{PO}_{4}$, and $5.5 \mathrm{mM}$ glucose; maintained at $37^{\circ} \mathrm{C}$ and bubbled with a mixture of $95 \% \mathrm{O}_{2}$ and $5 \% \mathrm{CO}_{2}$ ). One hook was fixed to the bottom of the bath, and the other was connected to a force transducer (Myograph F-60; Narco Bio-Systems, Houston, TX). The isometric responses of the tissue were recorded on a multichannel polygraph (Physiograph Mk111-S; Narco Bio-Systems). The tissues were then placed under 0.5 $\mathrm{g}$ tension and allowed to equilibrate in physiologic Krebs solution for $1 \mathrm{~h}$. During the equilibration period, the Krebs solution was replaced every $15 \mathrm{~min}$. After equilibration, the resting tension was adjusted in 0.25-g increments from 0.25 to $2.5 \mathrm{~g}$, and the maximal response to a modified oxygenated Krebs solution $(60 \mathrm{mM} \mathrm{KCl}, 66.7 \mathrm{mM} \mathrm{NaCl}, 1.2$ $\mathrm{mM} \mathrm{MgCl}, 2.5 \mathrm{mM} \mathrm{CaCl}_{2}, 15.4 \mathrm{mM} \mathrm{NaHCO}, 1.2 \mathrm{mM} \mathrm{KH}_{2} \mathrm{PO}_{4}$, and $5.5 \mathrm{mM}$ glucose) was measured at each resting tension to establish a length-tension relationship. Based on these results, the optimal resting tension for each ring (the tension at which the response to the modified Krebs solution was maximal) was determined, and the ring was set at this tension for subsequent studies. Norepinephrine $\left(10^{-9}-10^{-4} \mathrm{M}\right)$ was added cumulatively in half molar increments, and the isometric tension developed by the tissue was measured. After washout and reequilibration, dose-response curves were obtained for serotonin $\left(10^{-9}-10^{-4}\right.$ $M)$. The responses to each agonist were assessed with and without the presence of pertussis toxin $(100 \mathrm{ng} / \mathrm{ml}$ preincubated for $60 \mathrm{~min})$ or $\mathrm{NaF} / \mathrm{AlCl}_{3}$ solution $\left(10^{-3} \mathrm{M} \mathrm{NaF}\right.$ and $10^{-5} \mathrm{M} \mathrm{AlCl}_{3}$ preincubated for $30 \mathrm{~min}$ ). Additional jugular vein rings were assessed with and without the presence of pertussis toxin ( $200 \mathrm{ng} / \mathrm{ml}$ preincubated for $240 \mathrm{~min}$ ) to verify the results obtained at the lower concentration for $60 \mathrm{~min}$. All compounds were obtained from Sigma Chemical Company (St. Louis, MO).

\section{Adenylate measurements}

5-mm rings of external jugular vein were incubated at $37^{\circ} \mathrm{C}$ in Krebs solution for $30 \mathrm{~min}$ in the presence and absence of the $\mathrm{NaF} / \mathrm{AlCl}_{3}$ solution $\left(10^{-3} \mathrm{M} \mathrm{NaF}\right.$ and $\left.10^{-5} \mathrm{M} \mathrm{AlCl}_{3}\right)$. Thereafter, specimens were washed and snap frozen in liquid nitrogen for adenylate measurements. The frozen vein segments were ground to powder and dissolved in 300 $\mu \mathrm{l} 3 \mathrm{M}$ perchloric acid $\left(-10^{\circ} \mathrm{C}\right.$ for $\left.5 \mathrm{~min}\right)$. After centrifugation $(5,000$ 
A

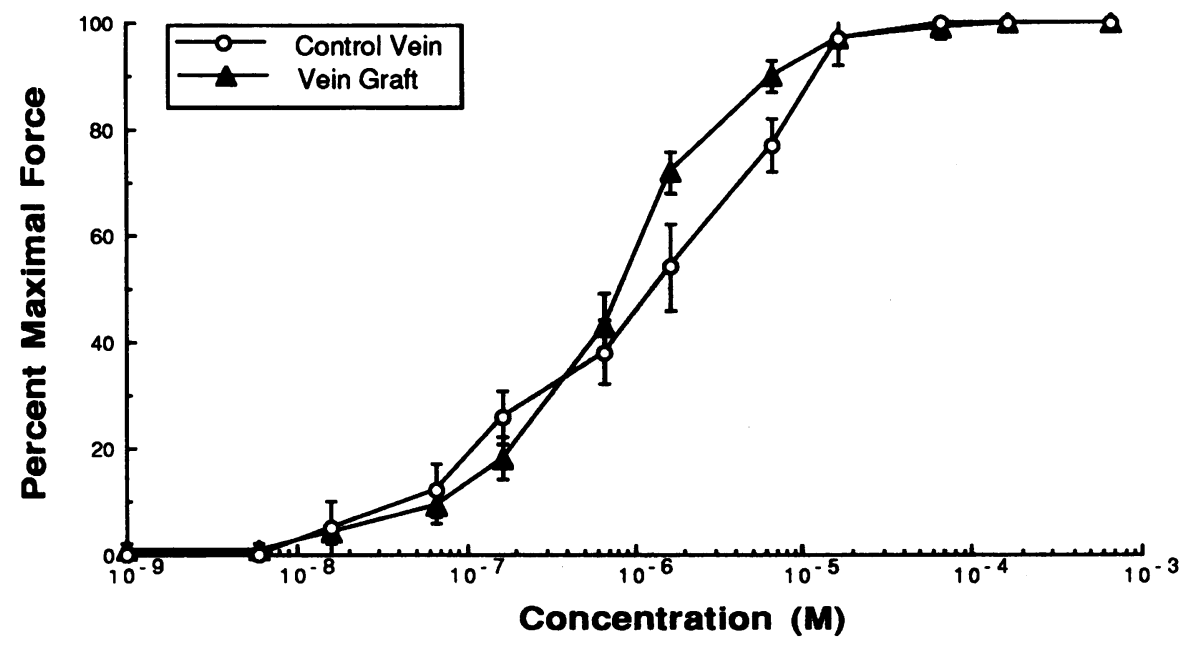

B
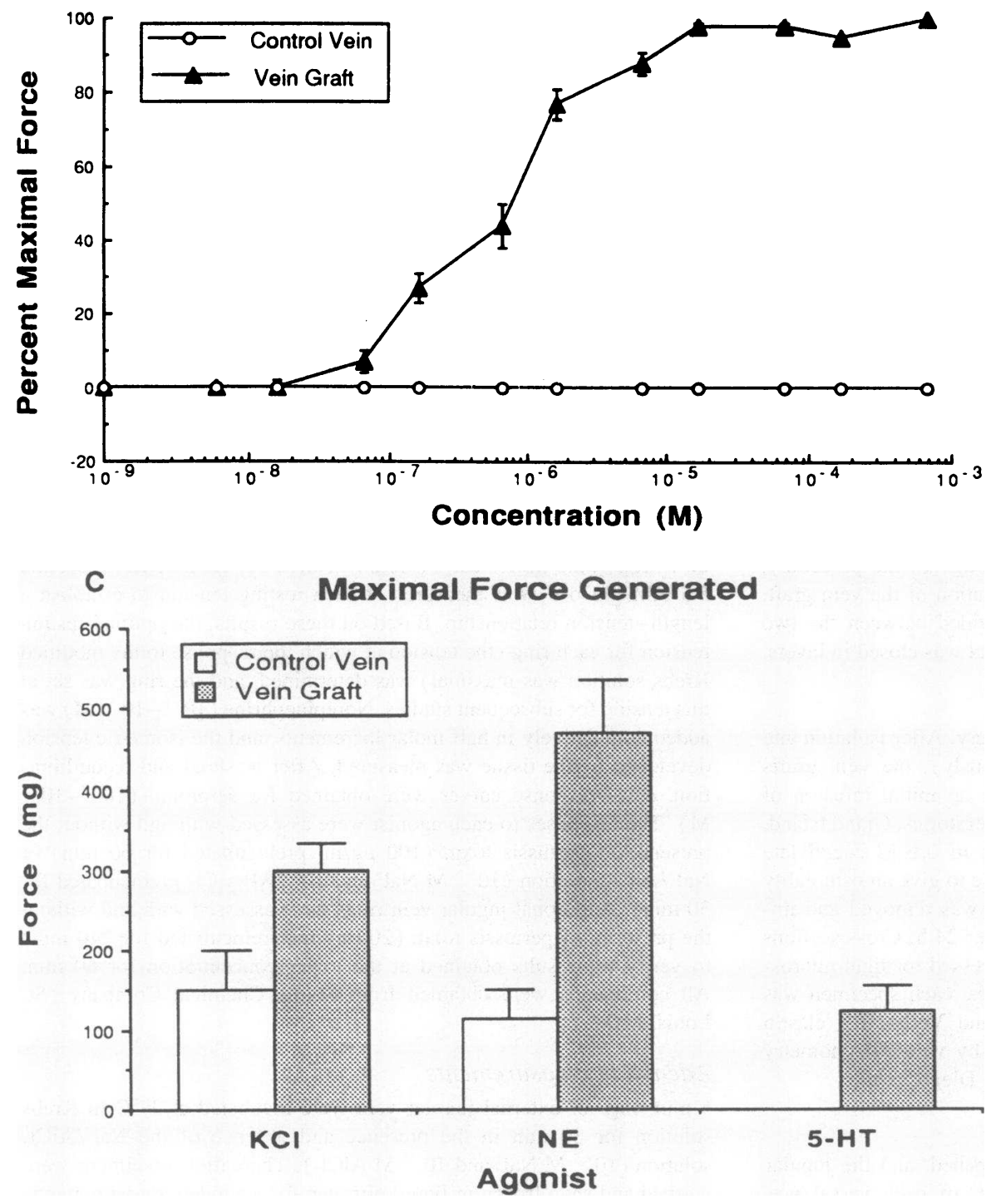

Figure 2. (A) The cumulative dose-response curves to norepinephrine in the jugular vein (o; $n=10$ animals, 20 rings) and the vein graft ( $\Delta ; n=10$ animals, 20 rings). Values are the mean \pm SEM percentage of maximal contractile force. The vein graft is more sensitive to norepinephrine than the vein with an $\mathrm{EC}_{50}$ of $6.21 \pm 0.09$ for the vein graft compared with $6.09 \pm 0.20$ for the vein $(P$ $<0.05$ ). (B) The cumulative dose-response curves to serotonin in the jugular vein $(0 ; n$ $=10$ animals, 20 rings) and the vein graft ( $\triangle ; n=10$ animals, 20 rings). Values are the mean $\pm S E M$ percentage of maximal contractile force. The vein did not contract to serotonin but the vein graft contracted with an $\mathrm{EC}_{50}$ of $6.20 \pm 0.14$. $(C)$ The maximal contractile force generated to potassium chloride $(60 \mathrm{mM})$, norepinephrine, and serotonin in the jugular vein and the vein graft. Values are the mean \pm SEM maximal contractile force in milligrams. There is a significant increase in the maximal contractile force to potassium chloride $(P=0.004)$, norepinephrine $(P=0.005)$, and serotonin in the vein graft. 
Table I. Changes in Sensitivity to Norepinephrine and Serotonin after Incubation with Pertussis Toxin

\begin{tabular}{lll}
\hline & Jugular vein & Vein graft \\
\hline Norepinephrine & & \\
Control & $6.09 \pm 0.20$ & $6.21 \pm 0.09$ \\
Pertussis toxin & $5.95 \pm 0.13$ & $5.16 \pm 0.35^{*}$ \\
Serotonin & & \\
Control & No response & $6.20 \pm 0.14$ \\
Pertussis toxin & No response & $5.54 \pm 0.26^{\ddagger}$ \\
\hline
\end{tabular}

The $\mathrm{EC}_{50}$ values to contractile agonists norepinephrine and serotonin in jugular veins and vein grafts with and without incubation with pertussis toxin $(100 \mathrm{ng} / \mathrm{ml}$ preincubated for $60 \mathrm{~min})$. The sensitivity of jugular veins incubated with pertussis toxin $200 \mathrm{ng} / \mathrm{ml}$ for $240 \mathrm{~min}$ had $\mathrm{EC}_{50}$ similar to the untreated controls $(6.17 \pm 0.25, P=\mathrm{NS})$. Values are the mean $\pm \mathrm{SEM}$ of the $\mathrm{pD}_{2}$ (defined as $\left.-\log _{10}\left[\mathrm{EC}_{50}\right]\right) . \quad * P=0.009$ and ${ }^{\ddagger} P=0.03$ compared with control vein graft.

$g, 10 \mathrm{~min}$ ), the supernatant was removed, neutralized with an equal volume of $2 \mathrm{M} \mathrm{KOH} / 2 \mathrm{M} \mathrm{KCl} / 0.4 \mathrm{M}$ Pipes solution, and recentrifuged to remove precipitated $\mathrm{KClO}_{4}$. The protein pellet was dissolved in 500 $\mu \mathrm{l} 1 \mathrm{M} \mathrm{NaOH}$, and the protein content was determined by the Bradford assay (10). Concentrations of ATP, ADP, and AMP in the extracts were determined using HPLC (LDC Analytical, Riviera Beach, FL) and system II as described by Schweinsberg and Loo (11) with a Milton Roy HPLC system (CM4000 solvent delivery system, spectroMonitor 3100 variable wavelength detector, set at $254 \mathrm{~nm}$, and a CI4100 integrator) and a spherisorb $\left(\mathrm{C}_{18}\right)$ column. The adenylate energy charge was calculated as $([\mathrm{ATP}]+0.5[\mathrm{ADP}]) /([\mathrm{ATP}]+[\mathrm{ADP}]+[\mathrm{AMP}])$ with the concentrations of each adenylate (ATP, ADP, and AMP) present in the samples expressed as picomoles per milligram of soluble protein.

\section{Protein analysis}

Membrane preparation. Membrane preparations were prepared as described previously $(12,13)$. The membrane pellets obtained by centrifugation $(27,000 \mathrm{~g}, 10 \mathrm{~min})$ were resuspended in $50 \mathrm{mM}$ Tris buffer $(\mathrm{pH}$ $7.4,37^{\circ} \mathrm{C}$ ), containing $10 \mathrm{mM} \mathrm{MgCl}, 1 \mathrm{mM}$ EDTA, and protease inhibitors ( $10 \mu \mathrm{g} /$ liter benzanidine, $10 \mu \mathrm{g} / \mathrm{ml}$ soybean trypsin inhibitor, and $2.5 \mu \mathrm{g} / \mathrm{ml}$ pepstatin). Membranes were solubilized in SDS-PAGE buffer ( $2 \mu \mathrm{g}$ protein per $\mu \mathrm{l}$ ) boiled for $10 \mathrm{~min}$ and then used for electrophoresis. Membrane protein concentrations were determined by the method of Bradford (10).

SDS-PAGE. Electrophoresis was performed according to the method of Laemmli (14) using homogenous slab gels, except that the concentration of acrylamide was $10 \%$ and the bisacrylamide concentration was $0.13 \%(13,15)$. After SDS-PAGE, the gels were transferred to nitrocellulose filters for Western blotting (vide infra).

Western blotting. For quantitating G-proteins, Western blotting experiments were performed essentially as described previously with some modification (12,13,16,17). Immunoblotting for $\mathrm{G} \alpha$ and $\beta$ subunits $\left(\alpha_{\mathrm{S}}, \alpha_{\mathrm{i} 1}, \alpha_{\mathrm{i} 2}, \alpha_{\mathrm{i} 3}, \alpha_{\mathrm{q}}, \alpha_{\mathrm{o}}\right.$, and $\beta$ subunits) was performed as described recently $(13,16)$. After electrophoresis, proteins were transferred to nitrocellulose ( $0.2 \mu \mathrm{m}$ BA83; Schleicher and Schuell, Inc., Keene, NH) at $100 \mathrm{~mA}$ for $3 \mathrm{~h}$ using a NovaBlot transfer unit (Pharmacia LKB Biotechnology Inc., Piscataway, NJ). Nonspecific binding was reduced by blocking the filters for $1 \mathrm{~h}$ at room temperature with a mixture of $5 \%$ (wt/vol) skim milk powder and $1 \mathrm{mM}$ EDTA/PBS solution (PBS: $136 \mathrm{mM} \mathrm{NaCl}, 2.7 \mathrm{mM} \mathrm{KCl}, 8.0 \mathrm{mM} \mathrm{Na}_{2} \mathrm{PO}_{4}$, and $15 \mathrm{mM} \mathrm{KH}_{2} \mathrm{PO}_{4}$, $\mathrm{pH} 7.5$ ) containing $0.2 \%$ ( $\mathrm{vol} / \mathrm{vol}$ ) of Triton $\mathrm{X}-100$. After this, the filters were incubated with $2 \mu \mathrm{g}$ of $\mathrm{IgG} / \mathrm{ml}$ in fresh blocking solution at $4^{\circ} \mathrm{C}$ overnight. The filters were then washed five times $(10 \mathrm{~min}$ per wash) with blocking solutions at room temperature and then incubated for $2 \mathrm{~h}$ with ${ }^{125} \mathrm{I}$-labeled goat anti-rabbit IgG in 5\% (vol/vol) skimmed milk/ $1 \mathrm{mM}$ EDTA/PBS and $0.1 \%$ (vol/vol) Triton X-100. After this, free radioactivity was removed by washing five times with blocking solutions (above) containing 1\% Triton X-100. The nitrocellulose was then air dried and exposed to Kodak XAR films with dual intensifying screens for 12-24 h. The respective autoradiograms for each G-protein were scanned by laser densitometry, and the integrated volume of the vein graft blot was expressed as a percentage of the volume of the same band in the blot from the jugular vein $(12,13)$.

Pertussis toxin-dependent ADP ribosylation. 5-mm rings of external jugular veins were incubated at $37^{\circ} \mathrm{C}$ in Krebs solution in the presence and absence of pertussis toxin $(100 \mathrm{ng} / \mathrm{ml}$ for $60 \mathrm{~min})$. Thereafter, specimens were washed and snap frozen in liquid nitrogen for ADP ribosylation measurements. Pertussis toxin-catalyzed labeling on membranes was performed with modifications according to the method of Owens $(12,18)$. Membranes $(\sim 100 \mu \mathrm{g}$ of protein) were incubated with $25 \mathrm{mM}$ 4-(2-hydroxyethyl)-1-piperazine-ethanesulfonic acid buffer ( $\mathrm{pH} 7.4$ ) containing $2.5 \mathrm{mM} \mathrm{MgCl}_{2}, 0.3 \mathrm{mM}$ EDTA, $10 \mathrm{mM}$ thymidine, $1 \mathrm{mM}$ ATP, $1 \mathrm{mM}$ DTT, and $5 \mu \mathrm{M}\left[{ }^{32} \mathrm{P}\right]$ NAD. Pertussis toxin was activated by incubating in buffer containing $50 \mathrm{mM}$ Tris- $\mathrm{HCl}$ (pH 7.4), $5 \mathrm{mM} \mathrm{MgCl}, 50 \mathrm{mM}$ DTT for $15 \mathrm{~min}$ at $37^{\circ} \mathrm{C}$ just before use. The final concentration of pertussis toxin was $30 \mu \mathrm{g} / \mathrm{ml}$. Incubations were for $15 \mathrm{~min}$ at $30^{\circ} \mathrm{C}$. After incubation, membranes were washed twice with ice cold buffer and pelleted in a microfuge. Membrane pellets were solubilized in buffer (10\% SDS, $10 \%$ glycerol, $20 \mathrm{mM}$ Tris- $\mathrm{HCl}$, $6 \% \beta$-mercaptoethanol, $\mathrm{pH} \mathrm{6.5)}$ for $1 \mathrm{~h}$ at room temperature before performing SDS-PAGE.

\section{RNA analysis}

RNA preparation and electrophoresis. Total cellular RNA was prepared by the guanidium isothiocyanate method $(16,17)$. The purity and concentration of samples from veins and vein grafts were estimated by ultraviolet (UV) spectrophotometry. Samples containing $\sim 12 \mu \mathrm{g}$ total RNA were added to 2-4 vol sample buffer in a total volume of $25 \mu$ l. Several steps were taken to ensure that equal amounts of RNA were loaded into each lane. First, RNA was quantitated by UV spectroscopy, and secondly, gels were stained with ethidium bromide to quantitate $18 \mathrm{~S}$ and $28 \mathrm{~S}$ ribosomal RNA. RNA sample buffer contained $160 \mathrm{ml}$ dye buffer $(5.0 \mathrm{ml}$ glycerol, $5 \mathrm{ml} 10 \times 1 \mathrm{M}$ Tris, $\mathrm{pH} 8.3,0.9 \mathrm{M}$ boric acid, $0.025 \mathrm{M}$ EDTA, $25 \mathrm{mg}$ bromophenol blue, and $25 \mathrm{mg}$ xylene cyanol), $720 \mu$ l deionized formamide, $160 \mu 110 \times$ Mops buffer, 260 $\mu \mathrm{l}$ formaldehyde $(37 \%)$, and $200 \mu \mathrm{l} \mathrm{H}_{2} \mathrm{O}$. RNA samples were first denatured by heating this mixture at $90^{\circ} \mathrm{C}$ for $10 \mathrm{~min}$ cooled on ice and resolved by electrophoresis using $1 \%$ agarose gels containing $0.2 \mathrm{M}$ formaldehyde, $1 \times$ Mops buffer, and $0.2 \mu \mathrm{g} / \mathrm{ml}$ ethidium bromide. Electrophoresis was performed at $85 \mathrm{~V}$ for $\sim 2 \mathrm{~h}$. RNA was then transferred to nylon membranes (Zeta probe; Bio-Rad Laboratories, Richmond, CA) and then crosslinked in a UV Stratalinker (Stratagene, La Jolla, CA).

Labeling oligonucleotide probes. Oligonucleotide probes were end labeled using $\left[\gamma^{32} \mathrm{P}\right] \mathrm{ATP}$ and $\mathrm{T}_{4}$ polynucleotide kinase (Bethesda Research Laboratories, Gaithersburg, MD) as described previously (17). Oligonucleotide probes for $\alpha_{S}$ were synthesized complementary to bases encoding amino acids 279-394 of the $\alpha_{\mathrm{S}}$ CDNA (19). The $\alpha_{\mathrm{i} 1}$ and $\alpha_{\mathrm{i} 2}$ probes were complementary to nucleotides encoding amino acids 118 133 and 109-124 of their respective $\alpha$ subunits (19). The oligonucleotide probe for $\alpha_{\mathrm{i} 3}$ was complementary to bases encoding amino acids $118-134$ of the $\alpha_{\mathrm{i} 3}$ protein.

Hybridization washing. Nylon membranes were prehybridized for $2 \mathrm{~h}$ at $42^{\circ} \mathrm{C}$ in $50 \%$ formamide, $2 \times$ Denhardt $(50 \times$ Denhardt contains $1 \%$ BSA, $1 \%$ polyvinylpyrolidine, and $1 \%$ Ficoll in RNase-free water), $5 \times$ SSC, $1 \%$ SDS, $200 \mu \mathrm{g} / \mathrm{ml}$ salmon sperm DNA, and $0.05 \%$ sodium pyrophosphate. After prehybridization, new hybridization buffer (50\% formamide, $3 \times$ Denhardt, $5 \times \mathrm{SSC}, 1 \% \mathrm{SDS}, 200 \mu \mathrm{g} / \mathrm{ml}$ salmon sperm DNA) containing $0.05 \%$ sodium pyrophosphate and $0.1 \mathrm{mg} / \mathrm{ml}$ tRNA was used. Hybridization was carried out with $\sim 6 \times 10^{5} \mathrm{cpm} / \mathrm{ml}$ of each probe. After incubation, blots hybridized with oligonucleotides 

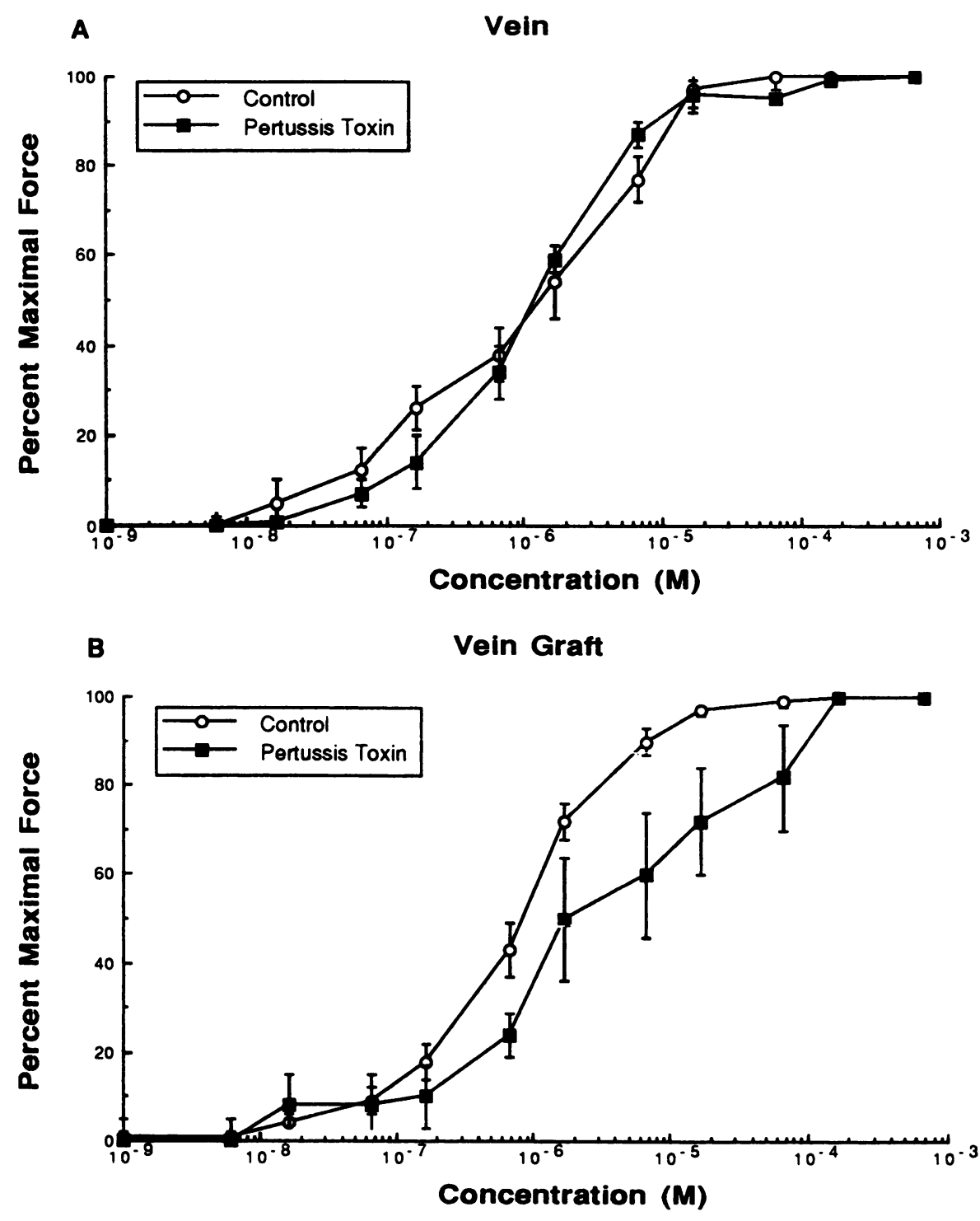

Figure 3. The cumulative dose-response curves to norepinephrine in the jugular vein ( $A ; n=10$ animals, 10 rings $)$ and in the vein graft ( $B ; n=10$ animals, 10 rings) before $(O)$ and after incubation with pertussis toxin (a). Values are the mean \pm SEM percentage of maximal contractile force, and the sensitivities are shown in Table I.

were washed three times ( $20 \mathrm{~min}$ each) at room temperature in $3.3 \times$ SSC containing $0.05 \%$ sodium pyrophosphate once (for $30 \mathrm{~min}$ ) at $55^{\circ} \mathrm{C}$ in $3.3 \times \mathrm{SSC}$ in the absence of sodium pyrophosphate and then twice (for $30 \mathrm{~min}$ ) at $55^{\circ} \mathrm{C}$ in $2 \times \mathrm{SSC}$. Transcripts were detected after autoradiography using Kodak XAR-5 $\mathrm{x}$-ray films with intensifying screens for 24-72 $\mathrm{h}$. The respective autoradiograms for each G-protein were scanned by laser densitometry, and the integrated volume of the vein graft blot was expressed as a percentage of the volume of the same band in the blot from the jugular vein. The level of RNA loaded per lane was determined by an RNA dye staining method (Nuclistain; National Diagnostics, Manville, NJ). The intensity of staining was determined by densitometric scanning of the blots.

\section{Data and statistical analysis}

The isometric responses of the rings were converted to percent maximal response. These values were then plotted against the negative logarithm of the agonist dose to produce dose response curves. The dose response curves were analyzed, and the concentration for half-maximal response $\left(\mathrm{EC}_{50}\right)^{1}$ value for contraction of each ring was calculated by logistic

1. Abbreviations used in this paper: $\mathrm{EC}_{50}$, concentration for half-maximal response; MLC, myosin light chain. analysis (20). The sensitivity of each agonist is measured as the $\mathrm{EC}_{50}$ and is expressed as $\mathrm{pD}_{2}$ (defined as $-\log \left[\mathrm{EC}_{50}\right]$ ). The maximal contractile response is expressed in milligrams of force developed. Data are presented as the mean \pm SEM. Statistical differences between groups were tested by one-way analysis of variance. A $P$ value $<0.05$ was regarded as significant.

\section{Results}

Morphology. The vein graft developed a significant degree of intimal hyperplasia compared with the control vein (Fig. 1). Microscopically, the intima of the control vein consisted of one layer of endothelial cells beneath which in the media there were a few layers of smooth muscle cells and connective tissue. The luminal surface of the vein graft was covered by a layer of intact endothelial cells. There was an uneven circumferential distribution of intimal hyperplasia that consisted of a high density of smooth muscle cells with only a little connective tissue seen between these cells. In the media of these vessels, there were several layers of slender smooth muscle cells, orientated 

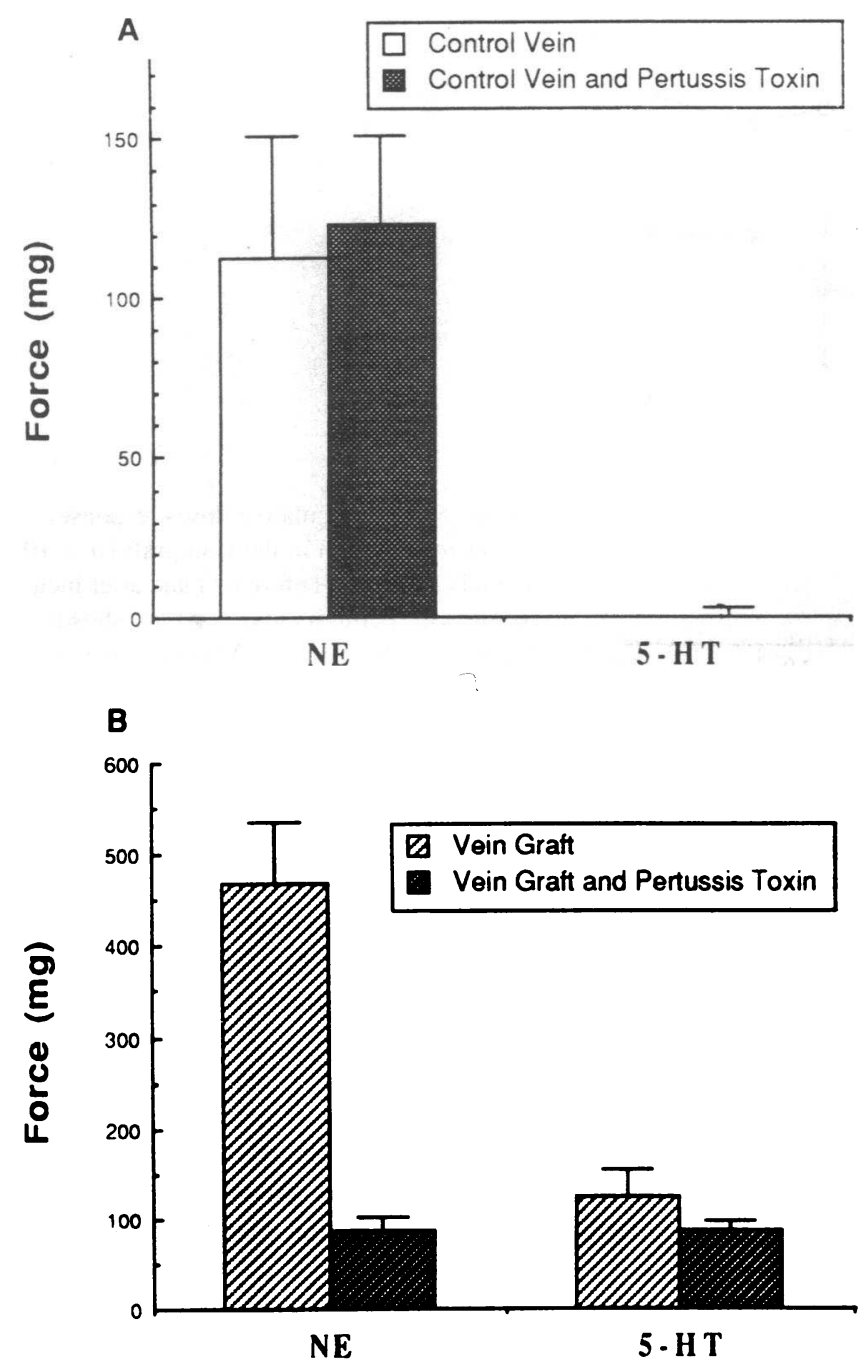

Figure 4. The maximal contractile force generated to norepinephrine and serotonin in the jugular vein $(A)$ and the vein graft $(B)$ before and after incubation with pertussis toxin are shown. Values are the mean \pm SEM maximal contractile force in milligrams.

in a circular pattern with a greater amount of collagen suggestive of hypertrophy of the media.

Vasomotor function. Norepinephrine produced sigmoid dose-response curves in both the jugular vein and the vein graft (Fig. 2, $A$ and $C$, and Table I), whereas serotonin produced a sigmoid dose-response in the vein graft only; the jugular vein did not respond to serotonin (Fig. 2, $B$ and $C$ ). The maximal response to potassium chloride and norepinephrine was increased in the vein grafts compared with the jugular veins. To determine a role of $G_{o}$ or $G_{i}$ proteins in the elevated responses to both norepinephrine and serotonin, tissues were incubated with pertussis toxin ( $100 \mathrm{ng} / \mathrm{ml}$ for $60 \mathrm{~min})$. Incubations with pertussis toxin did not attenuate the norepinephrine response in the jugular vein but did affect the response in the vein graft (Fig. 3, $A$ and $B$, and Table I); there was no change in the responses when pertussis toxin was incubated for a longer period $(240 \mathrm{~min})$ at a higher concentration $(200 \mathrm{ng} / \mathrm{ml})$ (Table I). In the presence of pertussis toxin, there was no change in the maximal contractile response to norepinephrine in the jugu- lar veins when compared with the untreated control jugular vein (Fig. $4 A$ ). In contrast, the maximal response of the vein grafts to norepinephrine was significantly attenuated and only reached a level of response similar to the jugular veins (Fig. $4 \mathrm{~B}$ ).

Preincubation of vein grafts with pertussis toxin induced a significant rightward shift of the serotonin dose-response curve (Fig. 5 and Table I). The maximal contractile response to serotonin in these vein grafts was reduced compared with untreated controls, but this was not statistically significant (Fig. $4 \mathrm{~B}$ ). To determine the efficacy of the ADP ribosylation with pertussis toxin in vitro, ADP ribosylation experiments were performed on membranes using $\left[{ }^{32} \mathrm{P}\right] \mathrm{NAD}$. The near complete lack of incorporation of $\left[{ }^{32} \mathrm{P}\right] \mathrm{ADP}$ ribose in the treated membranes compared with controls suggests a significant inactivation of the $G_{i}$ and $G_{0}$ proteins under the conditions used (Fig. 6).

Activation of G-proteins by fluoroaluminates interrupts their cyclic function, and decreases in receptor-mediated responses in the presence of $\mathrm{AlF}_{4}^{-}$are often viewed as additional evidence for the involvement of G-proteins in a physiological response. Pretreatment with $\mathrm{AlF}_{4}^{-}$attenuated the norepinephrine responses of both vessels with a significant decrease in the norepinephrine sensitivity (veins, 5.58 $\pm 0.12, P=0.05$; and vein grafts, $5.09 \pm 0.42, P=0.004$; values are the $\mathrm{pD}_{2}$, mean \pm SEM) compared with untreated vessels (Table I). Incubation of the vein graft with $\mathrm{AlF}_{4}^{-}$also reduced the sensitivity of the vein graft to serotonin $\left(\mathrm{pD}_{2}, 5.56 \pm 0.23, P=0.03\right)$ compared with untreated vein grafts (Table $I$ ). In addition to their influence on G-protein function, fluoroaluminates have been shown to interfere with glycolysis and, thus, these observed decreased agonist-mediated responses may reflect alterations in metabolism. Measurements of adenylate nucleotide levels showed that both ATP and AMP were detectable in control and $\mathrm{AlF}_{4}^{-}$treated jugular veins, but that ADP was only detectable in the untreated jugular veins. The adenylate energy charge $(0.64 \pm 0.09$ vs. $0.22 \pm 0.13 ; P$ $=0.06$ ) was decreased in the $\mathrm{AlF}_{4}^{-}$treated jugular veins. Therefore, the reduced responsiveness in the presence of fluoroaluminates can be explained by alterations in adenylate nucleotide levels of the vessels.

$G$-protein expression. To determine whether an increase in G-protein levels can contribute to the enhanced contractile responses to agonists, the levels of these proteins were quantitated by Western blotting using specific antibodies for G-protein $\alpha$ and $\beta$ subunits. There was a fivefold increase in $\alpha_{\mathrm{q}}$ expression $(5.0 \pm 0.5 ; n=3, P<0.01)$ and a 2.7 -fold increase in $\alpha_{\mathrm{i} 2}$ expression $(2.7 \pm 0.94 ; n=3, P<0.05)$ in the vein grafts compared with the jugular veins. While $\alpha_{\mathrm{i} 3}$ could be measured in the vein grafts, it was undetectable in the jugular veins. In addition to the elevation of the $\alpha_{i}$ and $\alpha_{q}$ subunits, there was a 3.3-fold increase in $\alpha_{\mathrm{S}}$ levels in the vein grafts compared with the jugular veins $(3.3 \pm 0.52 ; n=3, P<0.05)$. However, no detectable expression of the $\alpha_{0}$ or the $\alpha_{i 1}$ subunits was observed in either the jugular veins or vein grafts. Furthermore, the levels of the $\beta$ subunits were increased by 3.8 -fold in the vein grafts compared with the jugular veins $(3.8 \pm 0.25 ; n=3, P<0.01)$. Representative Western blots are shown in Figs. 7-9. mRNA for $\alpha_{\mathrm{S}}, \alpha_{\mathrm{i} 3}$, and $\alpha_{\mathrm{i} 2}$ were all elevated by approximately twofold in the vein grafts compared with the jugular veins (Fig. 10). No $\alpha_{i 1}$ transcript was identified. In addition, very little or undetectable levels of $\alpha_{\mathrm{i} 3}$ transcript were obtained in the veins. These data underscore the point that intimal hyperplasia in vein grafts 
Serotonin - Vein Grafts

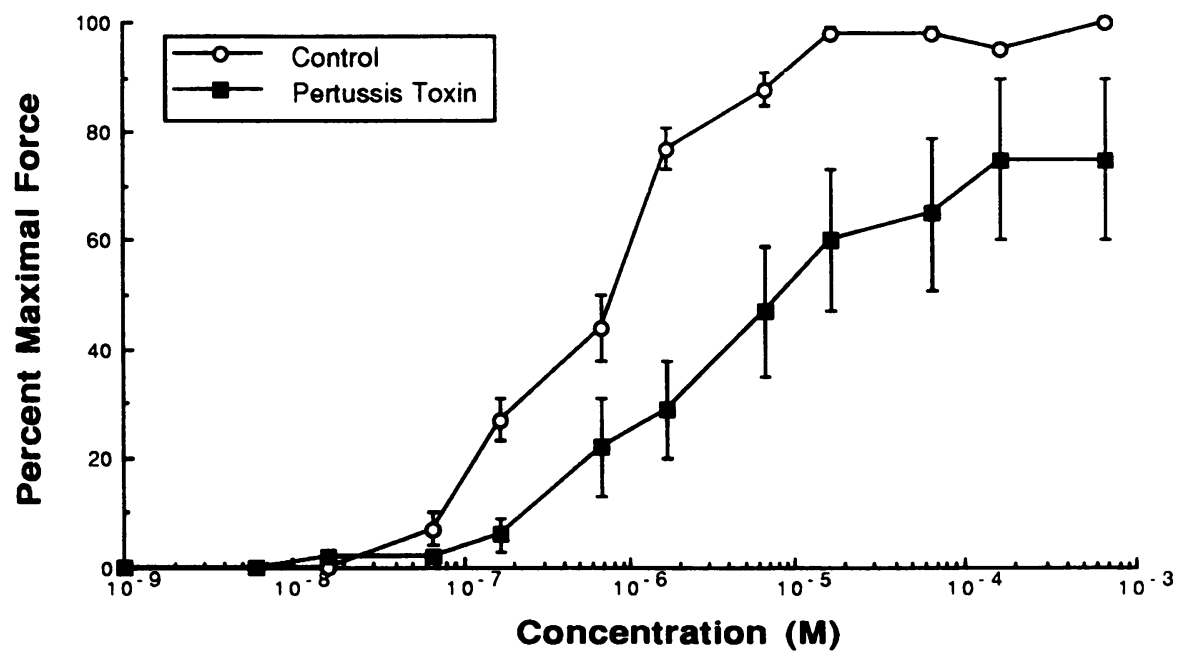

Figure 5. The cumulative dose-response curves to serotonin in the vein graft $(n=10$ animals, 10 rings) before $(O)$ and after incubation with pertussis toxin ( $\square$ ) are shown. Values are the mean \pm SEM percentage of maximal contractile force, and the sensitivities are shown in Table I. is associated with an increased expression or novel expression of G-proteins.

\section{Discussion}

Guanine nucleotide regulatory proteins (G-proteins) are a superfamily of GTP binding proteins that range from the heterotrimeric forms to monomeric forms, GAP-activated G-proteins, and ras-associated nuclear proteins (21). Functionally related GTP binding proteins are involved in signal transduction, protein synthesis, microtubule assembly, and oncogene function $(21,22)$. The heterotrimeric G-proteins are intrinsic membranebound proteins important in the trans-membrane signal transduction of cells (21-23). They have been shown to mediate, amplify, and regulate receptor activity and to activate intracellular secondary messenger/effector systems (23). Each heterotrimeric G-protein unit is composed of $\alpha, \beta$, and $\gamma$ subunits and can be classified according to differences in their $\alpha$ subunit (24). Further classification of G-proteins can be made based on the sensitivity of the receptor to G-protein coupling to pertus-

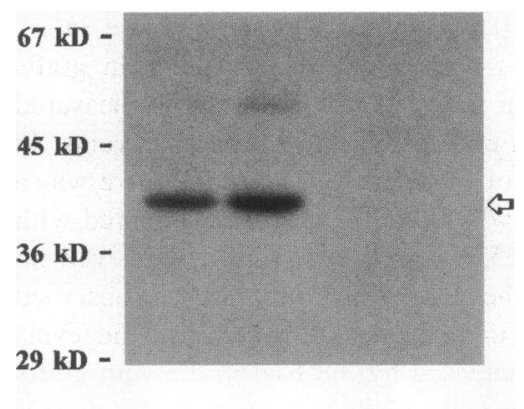

Figure 6. Representative experiment showing the levels of ADP ribosylation of pertussis toxinpretreated and untreated jugular veins and vein grafts. Lane 1 is an untreated jugular vein, lane 2 is an untreated vein graft, lane 3 is a pertussis toxin-pretreated jugular vein, and lane 4 is a pertussis toxin-treated vein graft. The lack of bands $\left(\alpha_{i}\right.$ proteins) in lanes 3 and 4 (arrow) suggests a lack of in vitro ADP ribosylation with [ $\left.{ }^{32} \mathrm{P}\right]$ NAD, indicating a significant degree of ADP ribosylation has occurred after pretreatment with pertussis toxin $(100 \mathrm{ng} / \mathrm{ml}$ incubated for 60 $\mathrm{min}$ ) in both the jugular vein and the vein graft. sis toxin (21). Pertussis toxin catalyzes the transfer of an ADP ribose moiety from NAD to a cysteine residue at the carboxyl terminus of the $\alpha_{i}$ proteins. This covalent modification and inactivation of $\alpha_{\mathrm{i}}$ abolishes receptor-mediated inhibition of adenylate cyclase and is associated with increases in both basal and stimulated cAMP levels $(21-23)$.

Intimal hyperplasia is characterized by early proliferation of smooth muscle cells and subsequent matrix deposition (1, 2 ). The lesion occurs at sites of arterial endarterectomy, arterial angioplasty, and in both prosthetic and venous bypass grafts (1). It is the principal pathological lesion responsible for the development of restenosis. This study has shown that intimal hyperplastic vessels possess increased concentrations of G-protein $\alpha_{\mathrm{s}}, \alpha_{\mathrm{i} 2}, \alpha_{\mathrm{q}}$, and $\beta$ subunits. In addition, the $\alpha_{\mathrm{i} 3}$ subunits were detectable in the vein grafts that have intimal hyperplasia but not in the jugular veins. These increases in G-proteins are associated with the development of enhanced pertussis toxinsensitive norepinephrine and serotonin contractile responses that are known to be coupled to G-proteins $(24,25)$. That there are pertussis toxin-sensitive responses suggests that the

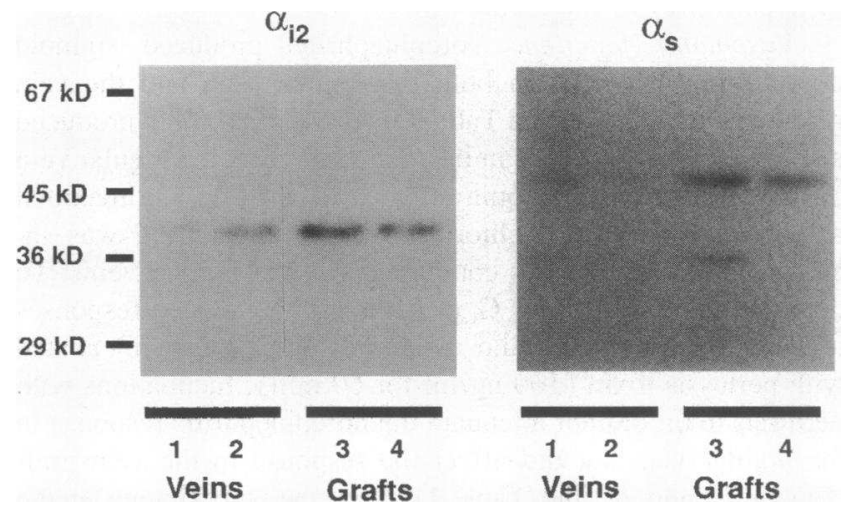

Figure 7. Representative Western blots of the expression of the $\alpha_{\mathrm{i} 2}$ and $\alpha_{\mathrm{s}}$ subunits in the jugular veins and vein grafts. There is a 2.7 -fold increase in the $\alpha_{\mathrm{i} 2}$ and a 3.3-fold increase in $\alpha_{\mathrm{S}}$ subunit levels in vein grafts compared with jugular veins. 

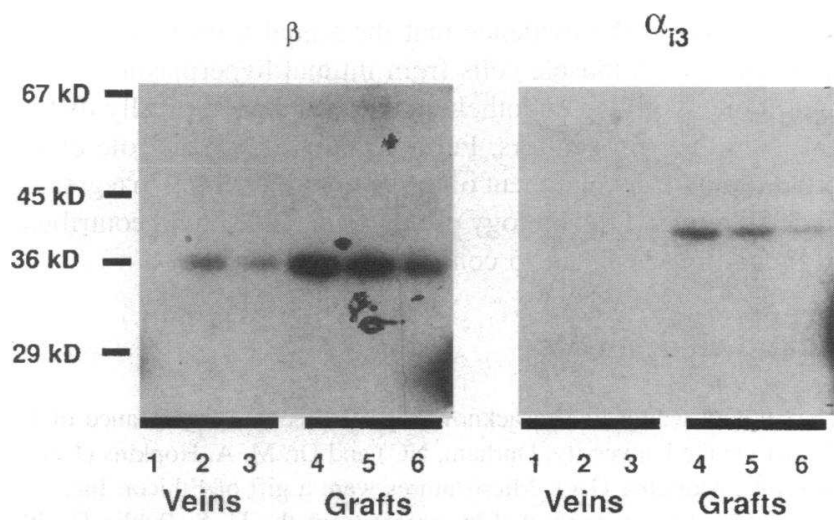

Figure 8. Representative Western blots of the expression of the $\alpha_{\mathrm{i} 3}$ and $\beta$ subunit in the jugular veins and vein grafts. There is a 3.8-fold increase in $\beta$ subunit levels in vein grafts compared with jugular veins. $\alpha_{\mathrm{i} 3}$ is detected in vein grafts only.

$\alpha_{\mathrm{i}}$ subunits are involved in the increased responses to norepinephrine and in the de novo serotonin responses in the vein grafts, even though in these vessels there were also increased levels of $\alpha_{\mathrm{q}}, \alpha_{\mathrm{i}}$, and $\alpha_{\mathrm{s}}$ and an absence of $\alpha_{\mathrm{o}}$.

The exact functions of the $\alpha_{\mathrm{i}}$ proteins are not clearly defined. There is good evidence that the $\alpha_{\mathrm{i} 2}$ species is coupled to the inhibition of adenylate cyclase, and it has been suggested that several $\alpha$ subunits may mediate the activation of the $\mathrm{K}^{+}$channel (26-28). The pertussis toxin-insensitive $\alpha_{\mathrm{q}}$ subunits have been shown to activate phospholipase $\mathrm{C} \beta(26-28)$. Thus, the large increase of $\alpha_{\mathrm{q}}$ subunits could explain the receptor-induced contractile response that remains in the presence of complete pertussis toxin-mediated ADP ribosylation. Serotonin-mediated contractile responses are not present in rabbit jugular veins but develop rapidly within $7 \mathrm{~d}$ in the vein bypass graft $(4,8)$. The maximal contractions generated by serotonin have been correlated with the development of the intimal hyperplasia. Antagonism after incubation with ketanserin, a 5- $\mathrm{HT}_{2}$ antagonist, has shown that this serotonergic contractile response results from the activation of 5-HT $\mathrm{HT}_{2}$ receptors (8). In this study, these $5-\mathrm{HT}_{2}-$ mediated contractions were also partially sensitive to pertussis toxin. Other workers have shown that the $5-\mathrm{HT}_{2}$ receptor-mediated phosphatidylinositol hydrolysis in cultured fi-

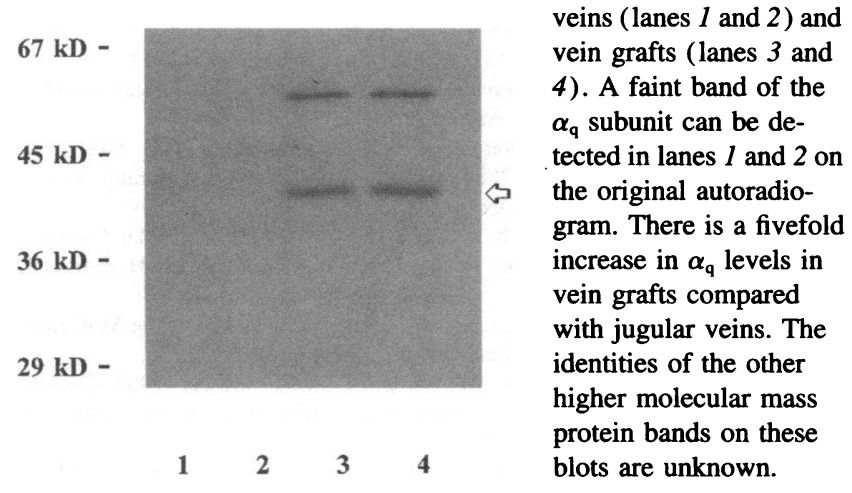

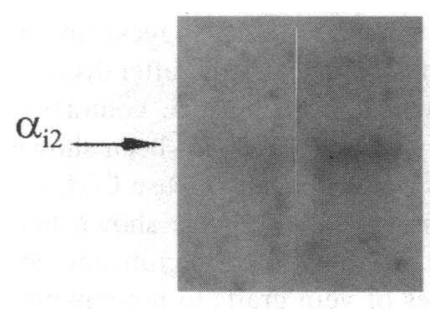

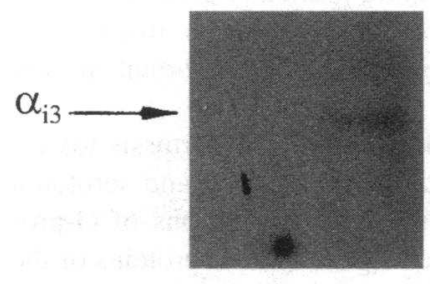

Figure 10. Representative Northern blots of the mRNA expression for the $\alpha_{\mathrm{i} 2}, \alpha_{\mathrm{S}}$, and $\alpha_{\mathrm{i} 3}$ subunits in the jugular veins (lane 1) and vein grafts (lane 2). There is no expression of the $\alpha_{i 1}$ in either vessel. Normalization of the blots by RNA staining (Nuclistain; National Diagnostics) indicate a $20 \%$ greater level of RNA loaded in lane 2 compared with lane 1. mRNA for $\alpha_{\mathrm{S}}, \alpha_{\mathrm{i} 3}$, and $\alpha_{\mathrm{i} 2}$ were all elevated by approximately twofold in the vein grafts compared with the jugular veins (average of two experiments).

broblasts can be abolished by ketanserin but that this response can only be inhibited by $\sim 50 \%$ after pretreatment with pertussis toxin $(25,29,30)$. These latter results are similar in many respects to those reported in this study, in that a known ketanserin-sensitive serotonin response ( 8 ) is only partially inhibited by pertussis toxin pretreatment. These findings could suggest that either there are two G-protein subtypes ( $\alpha_{i}$ and $\left.\alpha_{q}\right)$ involved in a 5-HT $\mathrm{H}_{2}$-mediated response or that there are two serotonin receptor subtypes $\left(5-\mathrm{HT}_{1}\right.$ and $5-\mathrm{HT}_{2}$ ) present. The data show that the increased maximal noradrenergic response in vein grafts is completely pertussis toxin sensitive, whereas in the jugular veins the noradrenergic response is insensitive, implying that it is $G_{q}$ mediated. However, after pertussis toxin pretreatment, the residual adrenergic response in the vein grafts, which is presumably $G_{q}$ mediated, is much less sensitive to norepinephrine than that observed in the jugular veins. This has occurred in spite of a fivefold increase in $\mathrm{G}_{\mathrm{q}}$ expression in the vein grafts. This difference is difficult to interpret but may suggest that some of the increased $G_{q}$ expression is not associated with the adrenergic response and may, in fact, be contributing to the pertussis toxin-insensitive portion of the de novo serotonin contractile response or other cellular functions not defined in this study.

In addition to the changes in the G-protein $\alpha$ subunits, there was also an increase in the $\beta$ subunits in the vein grafts. The traditional role of the $\beta \gamma$ subunits, released after activation of the $\alpha_{i}$ proteins, is to bind to the active $\alpha_{\mathrm{S}}$-GTP species, thus reducing their activity and leading to decreased cAMP levels. 
Therefore, an increase in $\beta \gamma$ subunits would suggest an increased inhibitory modulation of adenylate cyclase after dissociation of the $G_{i}$ heterotrimer, which may enhance contractile responses. Furthermore, the $\beta \gamma$ subunits have also been shown to activate phospholipase $\mathrm{C}$ isozymes (phospholipase $\mathrm{C}-\beta,-\gamma$, and $\delta)(31-34)$. Cross and associates (35) have shown that preincubation with indomethacin results in a significant decrease in the enhanced responses of vein grafts to norepinephrine, suggesting that this response may in part be prostanoid driven. This result, together with the emerging picture of the role of the $\beta \gamma$ subunits in activating particular secondary messengers and modulating the action of $\alpha_{\mathrm{s}}$ subunits, implies that the rises in $\beta$ subunits may be functionally important in vein graft vasoreactivity $(31-34)$.

In this study, there is the development of pertussis toxinsensitive responsiveness to both norepinephrine and serotonin with alterations in the subtypes and concentrations of G-proteins. It is conceivable that the changes in the G-proteins of the smooth muscle cells are part of the intimal hyperplastic reaction and that the changes in the contractile responses and in the Gproteins identify the particular smooth muscle phenotype present in the intimal hyperplasia of vein grafts. Agonists, such as norepinephrine and serotonin, can increase myosin light chain (MLC) phosphorylation through inhibition of MLC phosphatase via activation of G-proteins, and this enhanced MLC phosphorylation may be one of the principal mechanisms responsible for the enhanced contractile responses observed in the vein grafts (36). The significant increase in the $\mathrm{KCl}$-mediated responses in the vein grafts compared with the jugular veins suggests that mechanisms independent of G-proteins are also implicated. It must, therefore, be concluded on the basis of the data presented that, although the altered expression of G-proteins occurs in tandem with changes in the contractile responses, it may not solely be responsible for the enhanced contractile responses observed.

There is evidence to suggest that there are changes in the Gproteins of the endothelial cells overlying intimal hyperplastic lesions and in endothelial cells after exposure to arterial hemodynamic parameters in vitro. Vanhoutte and associates (37) have shown that the loss of endothelium-dependent relaxation in arteries that have developed intimal hyperplastic lesions after angioplasty is due to an altered response of a pertussis toxinsensitive G-protein. Cohen et al. (38) have shown in an in vitro study that endothelial cell $\alpha_{\mathrm{i}}$ immunoreactivity declines rapidly in $<15 \mathrm{~min}$ in response to "cyclic strain" on endothelial cell monolayers, coincident with a rise in adenylate cyclase activity. In view of the relatively long half-life of G-proteins, they suggested that there may be a transient posttranslational modification of $\alpha_{\mathrm{i} 1}$ and $\alpha_{\mathrm{i} 2}$ subunits with the initiation of cyclic strain, which could be due to prenylation/ribosylation of the subunits and which appears not to be due to carboxymethylation. However, neither prenylation nor ribosylation of G-proteins would lead to the loss of detectable immunoreactivity observed. Such rapid changes in G-proteins may contribute to the loss of endothelial cell regulation of the underlying smooth muscle cells and thus may be part of the pathophysiology of intimal hyperplasia.

In conclusion, this study demonstrates an increased expression of G-protein $\alpha$ and $\beta$ subunits in vein grafts, which might underlie the enhanced contractile responses to agonists in this intimal hyperplastic tissue and the onset of pertussis toxin sensitivity in the responses to norepinephrine and serotonin. These findings add to the evidence that the signal transduction pathways in smooth muscle cells from intimal hyperplastic lesions and in the overlying endothelial cells are phenotypically different from their progenitors. Further definition of the role of $G$ proteins in the development of this lesion is essential to a greater understanding of the biology of the lesion and should contribute to modalities designed to control its development.

\section{Acknowledgments}

The authors would like to acknowledge the technical assistance of $\mathrm{L}$. Barber (Duke University, Durham, NC) and Dr. M. A. Hopkins (CryoLife Inc., Marietta, GA). Microsutures were a gift of Ethicon Inc.

This study was supported by grants from the U. S. Public Health Service (HL-15448 and DK-42486). Dr. Davies is supported by a National Institutes of Health Fogarty International Research Fellowship (TW 04810) and holds a Royal College of Surgeons in Ireland Surgical Traveling Fellowship and a Trinity College Dublin Postgraduate Scholarship.

\section{References}

1. Chervu, A., and W. S. Moore. 1990. An overview of intimal hyperplasia Surg. Gynecol. \& Obstet. 171:433-447.

2. Cox, J. L., D. A. Chiasson, A. I. Gottlieb. 1991. Stranger in a strange land: the pathogenesis of saphenous vein graft stenosis with emphasis on structural and functional differences between veins and arteries. Prog. Cardiovasc. Dis. 34:4568.

3. Cross, K. S., M. N. El-Sanadiki, J. J. Murray, E. M. Mikat, R. L. McCann, and P.-O. Hagen. 1988. Functional abnormalities of experimental autogenous vein graft neoendotheium. Ann. Surg. 208:631-638.

4. Makhoul, R. G., W. S. Davis, E. M. Mikat, R. L. McCann, and P.-O. Hagen. 1987. Responsiveness of vein grafts to stimulation with norepinephrine and 5-hydroxytryptamine. J. Vasc. Surg. 6:32-38.

5. Ku, D. D., J. B. Caufield, and J. K. Kirklin. 1991. Endothelium-dependent responses in long term human coronary artery bypass grafts. Circulation. 83:402411

6. Steen, S., R. Willen, T. Sjoberg, and B. Carlen. 1991. Contractile and morphologic properties of a saphenous vein after 12 years as an aortocoronary bypass graft. Blood Vessels. 28:349-353.

7. Soliman, A. S., and R. L. Tackett. 1992. Early alterations in vascular reactivity of autogenous saphenous vein grafts. Coron. Artery Dis. 3:523-527.

8. Radic, Z. S., M. K. O'Donohoe, L. B. Schwartz, A. D. Stein, E. M. Mikat, R. L. McCann, and P.-O. Hagen. 1991. Alterations in serotonergic receptor expression in experimental vein grafts. J. Vasc. Surg. 14:40-47.

9. Ross, R. 1986. The pathogenesis of atherosclerosis: an update. N. Engl. J. Med. 314:488-500.

10. Bradford, M. M. 1976. A rapid and sensitive method for the quantitation of microgram quantities of protein utilizing the principle of dye binding. Anal. Biochem. 72:248-254.

11. Schweinsberg, P. D., and T. L. Loo. 1980. Simulataneous analysis of ATP, ADP, AMP and other purines in human erythrocytes by high performance liquid chromatography. J. Chromatogr. 181:103-107.

12. Ramkumar, V., and G. L. Stiles. 1990. In vivo pertussis toxin administration: effects on function and levels of $\mathrm{G}_{\mathrm{i} \alpha}$ proteins and their messenger RNA. Endocrinology. 126:1295-1304.

13. Raymond, J. R., C. L. Olsen, and T. W. Gettys. 1993. Cell specific physical and functional coupling of human 5-HT ${ }_{1 \mathrm{~A}}$ receptors to inhibitory $\mathrm{G}$ protein $\alpha$ subunits and lack of coupling to $\mathrm{G}_{\mathrm{s} \alpha}$. Biochemistry. 32:11064-11073.

14. Laemmli, U. K. 1970. Cleavage of structural proteins during the assembly of the head of bacteriophage $\mathrm{T}_{4}$. Nature (Lond.). 227:680-685.

15. Goldsmith, P., K. Rossiter, A. Carter, W. Simonds, C. G. Unson, R. Vinitsky, and A. M. Spiegel. 1988. Identification of the GTP-binding protein encoded by $\mathrm{G}_{\mathrm{i} 3}$ complementary DNA. J. Biol. Chem. 263:6476-6479.

16. Maniatis, T., E. F. Fritsch, and J. Sambrook. 1982. Molecular Cloning: A Laboratory Manual. Cold Spring Harbor Laboratory, Cold Spring Harbor, NY. 194-195.

17. Davis, C. D., M. D. Dibner, and J. F. Batte. 1986. Methods in Molecular Biology. Elsevier Science Publishing Co. Inc., New York. 130-135.

18. Owens, J. R., L. T. Frame, M. Wi, and D. M. F. Cooper. 1984. Cholera toxin ADP ribosylates the islet activating protein substrate in rat adipocytes. $J$. Biol. Chem. 260:15946-15952.

19. Brann, M. R., R. M. Collins, and A. Spiegel. 1987. Localization of mRNA 
encoding the $\alpha$ subunits of signal transducing G-proteins within rat brain and among peripheral tissues. FEBS (Fed. Eur. Biochem. Soc.) Lett. 222:191-198.

20. Finney, D. J. 1978. Quantal responses and the tolerance distribution. In Statistical Methods in Biological Assay. D. J. Finney, editor. Charles Griffin \& Co., Ltd., London. 349-369.

21. Gilman, A. G. 1987. G-Proteins: transducers of receptor-generated signals. Annu. Rev. Biochem. 56:615-649.

22. Robishaw, J. D., and K. A. Foster. 1989. Role of G-proteins in the regulation of the cardiovascular system. Annu. Rev. Physiol. 51:229-244.

23. Neer, E. J., and D. E. Clapham. 1988. Roles of G-protein subunits in transmembrane signaling. Nature (Lond.). 333:129-134.

24. Bylund, D. B. 1992. Subtypes of $\alpha_{1}$ - and $\alpha_{2}$-receptors. FASEB (Fed. Am. Soc. Exp. Biol.) J. 6:832-839.

25. Fozard, J. 1987. 5-HT: the enigma variations. Trends Pharmacol. Sci. 8:501-506.

26. Kaziro, Y., H. Itoh, T. Kozasa, M. Nakafuku, and T. Satoh. 1991. Structure and function of signal transducing GTP-binding proteins. Annu. Rev. Biochem. 60:349-400.

27. Spiegel, A. M. 1987. Signal transduction by guanine nucleotide binding proteins. Mol. Cell. Endocrinol. 49:1-16.

28. Taussig, R., J. A. Inigues-Lluhi, and A. G. Gilman. 1993. Inhibition of adenylyl cyclase by $\mathrm{G}_{\mathrm{i} \alpha}$. Science (Wash. DC). 261:218-221.

29. Seuwen, K., I. Magnaldo, and J. Pouyssegur. 1988. Serotonin stimulates DNA synthesis in fibroblasts acting through 5-HT ${ }_{18}$ receptors coupled to a $\mathrm{G}_{\mathrm{i}}$ protein. Nature (Lond.). 335:254-256.

30. Ui, M. 1984. Islet-activating protein, pertussis toxin: a probe for functions of the inhibitory guanine nucleotide regulatory component of adenylate cyclase. Trends Pharmacol. Sci. 5:277-279.

31. Blank, J. L., K. A. Brattain, and J. H. Exton. 1992. Activation of cytosolic phosphosinositide phospholipase C by G-protein beta and gamma subunits. $J$. Biol. Chem. 267:23069-23075.

32. Camps, M., C. Hou, D. Sidiropoulos, J. B. Stock, K. H. Jakobs, and P. Gierschik. 1992. Stimulation of phospholipase $\mathrm{C}$ by guanine nucleotide binding by beta gamma units. Eur. J. Biochem. 206:821-831.

33. Boyer, J. L., G. L. Waldo, and T. K. Harden. 1992. Beta-gamma subunits activation of G-protein regulated phospholipase C. J. Biol. Chem. 267:26451 25466 .

34. Park, D., D.-Y. Jhon, C.-W. Lee, K.-H. Lee, and S.-G. Rhee. 1993. Activation of phospholipase $\mathrm{C}$ isozymes by G-protein $\beta \gamma$ subunits. J. Biol. Chem. 268:4573-4576.

35. Cross, K. S., M. N. El-Sanadiki, J. J. Murray, R. L. McCann, and P.-O. Hagen. 1987. The role of prostaglandins in the altered vasoreactivity of autogenous vein grafts to norepinephrine and histamine. Circulation. 76:482a. (Abstr.)

36. Kitazawa, T., M. Masuo, and A. Somlyo. 1991. G protein-mediated inhibition of myosin light-chain phosphatase in vascular smooth muscle. Proc. Natl. Acad. Sci. USA. 88:9307-9310.

37. Shimokawa, H., N. A. Flavahan, and P. M. Vanhoutte. 1989. Natura course of the impairment of endothelium dependent relaxations after endothelium removal in porcine arteries: possible dysfunction of a pertussis toxin-sensitive $G$ protein. Circ. Res. 65:740-753.

38. Cohen, C. R. G., I. Mills, and B. E. Sumpio. 1992. Are G-proteins mechanotransducers for endothelial cells? Surgical Forum. XLIII:327-329. 